\title{
Pelatihan Membangun Karakter Anak dengan NLP (Neuro Linguistic Programming) Untuk Anggota TP-PKK Desa Kumutug Lor Banyumas
}

\author{
Ade Tuti Turistiati ${ }^{1}$, Angel Septia Anggreani ${ }^{2}$, Eyora Jasmine Nan Kinasih ${ }^{3}$ \\ Program Studi Ilmu Komunikasi, Fakultas Bisnis dan Ilmu Sosial, Universitas Amikom Purwokerto \\ ade.tuti@amikompurwokerto.ac.id
}

\begin{abstract}
ABSTRAK
Pembelajaran secara daring di masa pandemi Covid-19 seringkali membuat komunikasi antara orang tua dan anak menjadi masalah. Orang tua menganggap anaknya lebih banyak menghabiskan waktu menggunakan gadget untuk keperluan di luar belajar, seperti untuk bermain games, menonton tayangan di kanal Youtube, berinteraksi dengan teman melalui media sosial, dan berselancar mengakses berbagai informasi. Anak-anak berdalih bahwa gadget-nya digunakan untuk keperluan belajar. Ketegangan hubungan dan miskomunikasi antara orang tua dan anak pun sering terjadi karena adanya perbedaan persepsi tersebut. Orang tua berharap anak-anaknya mempunyai karakter yang baik. Kegiatan pengabdian pada masyarakat ini bertujuan untuk membantu anggota Tim Penggerak-PKK desa Kemutug Lor, Banyumas dalam membangun karakter anak dengan presuposisi NLP. Dosen sebagai Fasilitator dibantu 2 orang mahasiswa memberikan materi pelatihan kepada TP-PKK yang berjumlah 25 orang. Materi pelatihan disampaikan secara interaktif. Fasilitator melibatkan peserta dalam sharing, diskusi, role play, dan perenungan untuk evaluasi dan perbaikan diri. Berdasarkan evaluasi pasca pelatihan, peserta menyatakan bahwa mereka merasakan manfaat praktis dari pelatihan ini. Mereka mempunyai bekal pengetahuan dan tips berkomunikasi dengan presuposisi NLP yang telah dipahami dan akan dipraktikkan dalam kehidupan sehari-hari dalam membangun karakter anak.
\end{abstract}

Kata kunci: Komunikasi, Membangun Karakter, Pelatihan, NLP

\section{ABSTRACT}

Online learning during the Covid-19 pandemic often makes communication between parents and children a problem. Parents consider their children to spend more time using gadgets not for learning purposes, such as playing games, watching various programs via YouTube channel, interacting with friends via social media, and browsing various information. The children argued that their gadgets were used for learning purposes. Relationship tensions and miscommunication between parents and children often occur because of these different perceptions. Parents hope their children have good character. This community service activity aims to help the members of the Kemutug Lor Village TPPKK Team, Banyumas in building children's character with the NLP presupposition. Lecturer as a facilitator, assisted by 2 students, provided training materials to 25 members of TP-PKK. The training material is delivered interactively. The facilitator engaged participants in sharing, discussion, role play, and reflection for self-evaluation and improvement. Based on the post-training evaluation, participants stated that this training is very practical. They have the knowledge and tips to communicate using the NLP presuppositions that have been understood and will be implemented in building children's character.

Keywords: Communication, Build Character, Training, NLP

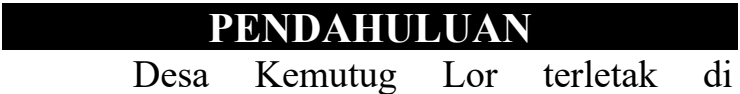

Kecamatan Baturraden, Kabupaten Banyumas dengan jumlah penduduk sekitar 6.000 jiwa. Mata pencaharian masyarakat desa sebagian besar dalam bidang pertanian dan perdagangan. Kemutug Lor memiliki fasilitas Pendidikan Anak Usia dini (PAUD), Sekolah Dasar Negeri, pesantren, dan lembaga kejar paket B dan paket C. Penduduk desa Kemutug Lor sebagian besar masih tamatan $\mathrm{SD}$, terutama mereka yang berusia lanjut. Kini penduduk yang tamatan SMP dan SMA telah banyak dan beberapa menjadi sarjana (Wikipedia, 2021).

Dalam rangka memberdayakan keluarga untuk tercapainya keluarga yang sejahtera, berakhlak mulia dan berbudi luhur, Kepada Desa Kemutug Lor mengaktifkan Tim Penggerak Pemberdayaan dan Kesejahteraan Keluarga (TP-PKK). Anggota TP-PKK di desa 
Kemutug Lor adalah ibu-ibu yang pada umumnya mempunyai anak-anak yang bersekolah di tingkat TK-SMA atau mempunyai cucu di TK-SD.

Pada masa pandemi Covid-19 proses pembelajaran siswa termasuk anak-anak sekolah di desa Kemutug Lor menggunakan metode online atau daring. Mayoritas anakanak sekolah menggunakan HP untuk proses pembelajaran. Banyaknya waktu yang digunakan anak menggunakan HP baik untuk keperluan pembelajaran maupun penggunaan lainnya seperti menggunakan media sosial, menonton berbagai tayangan di Youtube, main games, dan lain-lain, sering memicu pertikaian antara orang tua terutama ibu dengan anaknya.

Berdasarkan wawancara dengan anggota TP-PKK Desa Kemutug Lor, kondisi sekarang sulit membangun karakter anak. Anak-anak banyak menghabiskan waktu di rumah dan kegiatannya lebih banyak dengan menggunakan HP. Anak-anak baik di tingkat SD, SMP maupun SMA cenderung sulit dinasihati, misalnya untuk melaksanakan kewajiban beribadah (shalat) tepat waktu bagi yang beragama Islam dan membantu orang tua mengerjakan pekerjaan rumah, serta tugastugas sekolah. Anak-anak sering sibuk dengan gadget-nya sehingga orang tua perlu memanggil berkali-kali ketika anaknya dibutuhkan. Anak-anak banyak yang tidak dapat mengatur waktu antara mengerjakan kewajibannya sebagai pelajar dan melakukan hal-hal yang disenanginya. Kondisi tersebut sering memicu perselisihan antara anak dan orang tua. Di sisi lain, orang tua merasa khawatir jika anaknya keluar rumah dan bergaul atau berkerumun dengan teman-temannya karena berpotensi terpapar Covid-19.

Orang tua, terutama para ibu memerlukan cara atau metode bagaimana menyampaikan pesan, nasihat, dan ajakan pada anak agar apa yang disampaikannya dipahami anaknya dengan baik dan anaknya berkenan melakukan apa yang diharapkan orang tua. Intinya orang tua berharap mereka dapat membangun karakter anaknya dengan baik.

Program pengabdian kepada masyarakat ini bertujuan untuk membantu ibuibu yang tergabung dalam TP-PKK desa Kemutug Lor dalam membangun karakter anaknya dengan baik. Presuposisi Neuro Linguistic Program dipilih sebagai pendekatan dalam membangun karakter anak karena presuposisi NLP relatif mudah dipahami dan dapat diaplikasikan dalam kehidupan seharihari.

"Neuro Linguistic Programming atau

NLP merupakan suatu metodologi yang berasumsi bahwa semua pemikiran dan tindakan mempunyai struktur. Struktur tersebut bisa dipelajari, dimodel, diajarkan, dan diubah atau diprogram kembali" (Hingdranata, 2014). Untuk melaksanakan metode NLP tersebut, kita mengacu pada presuposisi NLP. Presuposisi adalah anggapan atau pendapat yang dianggap benar tanpa perlu dibuktikan.

Penelitian-penelitian terdahulu dengan menggunakan metode NLP telah banyak dilakukan, baik dalam lingkup pendidikan antara guru dan siswa, hubungan antar pegawai di perusahaan, maupun hubungan sosial atau interaksi antar manusia sehari-hari. Beberapa penelitian terdahulu menunjukkan metode NLP dapat meningkatkan hubungan baik antar individu.

Penelitian di Indina menemukan bahwa guru-guru bahasa Inggris di sekolah menengah atas yang dilatih NLP dapat berkomunikasi lebih efektif dengan para siswanya. Komunikasi yang terjalin dengan baik ketika mengajar bahasa Inggris menciptakan lingkungan belajar interaktif dan menyenangkan bagi guru dan siswa. Para siswa semangat belajar sehingga nilai bahasa Inggris mereka pun lebih baik. Selain itu, para siswa berani berbicara dalam bahasa Inggris dengan nyaman (Keezhatta, 2019).

Penelitian lain dilakukan pada para pengusaha yang mengalami kegagalan dalam usahanya sehingga kehilangan rasa percaya diri dalam melakukan pekerjaan. Akibatnya, kinerja mereka pun ikut menurun bahkan mengalami hambatan dalam melakukan komunikasi dengan orang lain. Setelah mengikuti pelatihan NLP dan berpedoman para presuposisi dalam NLP, motivasi mereka pun bangkit dan bersemangat kembali untuk menghasilkan kinerja yang prima. Selain itu, mereka merasa nyaman dalam berkomunikasi dengan orang lain (Nurul Yani, 2018).

Gaya dan konten komunikasi orang tua berperan penting dalam membangun karakter anak (Turistiati, 2019). Sehingga, orang tua perlu mempunyai bekal pengetahuan dan pemahaman bagaimana berkomunikasi dalam rangka membangun karakter anak. 


\section{METODE KEGIATAN}

Metode kegiatan PKM berupa pelatihan ini dibagi ke dalam beberapa tahap. Secara umum tahapannya dibagi ke dalam prapelatihan, pelatihan, dan pasca pelatihan sebagai berikut:

\section{1) Pra-Pelatihan}

a. Survey

Fasilitator mempelajari fenomena yang terjadi di desa Kemutug Lor di mana orang tua (ibu-ibu) menghadapi permasalahan dalam membangun karakter anak-anaknya. Selain itu, mereka merasa kesulitan berkomunikasi secara efektif dengan anakanaknya yang dianggap terlalu banyak menghabiskan waktu dengan gadget-nya dan menonton TV.

b. Diskusi dan merumuskan masalah serta menentukan alternatif solusi.

Fasilitator berdiskusi dengan perwakilan TP-PKK desa Kemutug Lor untuk merumusan masalah dan mencari solusi. Berdasarkan diskusi, fasilitator perwakilan TP-PKK setuju fasilitator mengadakan pelatihan membangun karakter anak dengan pendekatan Neuro Linguistic Program (NLP). Fasilitator memberikan penjelasan singkat mengenai NLP mengingat mereka belum pernah mendengar dan mengetahui sama sekali pendekatan tersebut.

c. Menyusun materi pelatihan dan alat Evaluasi

Fasilitator menyusun materi pelatihan dalam bentuk PPT dan booklet sederhana yang digunakan dalam proses pelatihan. Alat evaluasi dibuat untuk mengetahui hasil atau efektif tidaknya pelatihan yang telah dilaksanakan, mengetahui manfaat yang diperoleh, dan mengetahui rencana yang akan dilaksanakan oleh para peserta dalam mengimplementasikan pengetahuan dan pemahaman yang diperolehnya.

\section{2) Melaksanakan pelatihan}

Pelatihan dilaksanakan di desa Kemutug Lor pada tanggal 1 April 2021, dari pukul 09:00-12:00. Pelatihan berlangsung secara interaktif, diselingi permainan dengan tema "sugesti", diskusi, tanya jawab, dan role play.

\section{3) Pasca pelatihan}

Setelah pelatihan dilaksanakan, fasilitator memberikan lembar evaluasi yang berisi pertanyaa tentang: apa saja yang mereka pelajari dari pelatihan tersebut; manfaat apa yang diperoleh; bagaimana rencana para peserta menerapkan pengetahuan dan pemahaman yang diperoleh dalam rangka membangun hubungan baik dengan anak sekaligus membangun karakter anak; masukan dan saran peserta mengenai pelatihan dan kebutuhan pelatihan di masa yang akan datang.

\section{HASIL \& PEMBAHASAN}

Pelatihan ini dilaksanakan secara tatap muka di aula balai desa Kemutug Lor dengan menerapkan protokol kesehatan. Acara pelatihan dibuka oleh Kepala Desa Kemutug Lor. Fasilitator memulai pelatihan dengan mengadakan acara perkenalan dan permainan untuk mencairkan suasana. Para peserta nampak antusias dengan pelatihan yang diadakan.

Materi pelatihan disampaikan dengan cara interaktif dibantu penayangan slide presentation. Materi yang diberikan fasilitator mengacu pada presuposisi yang ada dalam NLP. NLP memiliki 20 (dua puluh) presuposisi. Dalam pelatihan ini disampaikan 8 presuposisi yang relevan dengan topik PKM, yaitu sebagai berikut:

1) Makna dari komunikasi adalah respon yang kita dapat.

Individu bertanggung jawab untuk mendapatkan respon yang ia inginkan dari partner komunikasi. Apapun yang ia terima dari partner komunikasi, itu adalah indikasi efektifitas komunikasinya. Nilai keberhasilan sebuah komunikasi terletak dari apa respon orang lain, bukan dari apa yang menurut individu telah dikomunikasikan. Orang tua kadangkadang merasa bahwa mereka telah menyampaikan pesan dengan baik. Sehingga, orang tua cenderung menyalahkan anaknya jika pesan yang disampaikan tidak dipahami atau diikuti oleh anak. Presuposisi ini menjelaskan bahwa efektifitas komunikasi dapat dilihat dari respon yang diterima. Dalam hal ini orang tua dapat melakukan evaluasi diri apakah konten dan gaya komunikasinya dengan anak sudah tepat. Konten yang disampaikan bisa jadi sudah pas namun cara atau gaya menyampaikannya yang masih perlu diperbaiki. Orang tua perlu melakukan konfirmasi apakah pesan yang telah disampaikannya sudah secara efektif diterima anaknya. 
Fasilitator memberikan contoh bagaimana gaya komunikasi sangat berpengaruh pada efektifitas komunikasi. Gaya komunikasi yang agresif dengan menyerang kepribadian anak (personal attack) sedemikian rupa harus dihindari orang tua ketika berkomunikasi dengan anak. Misalnya: "Kamu susah jika dinasihati", "Kamu memang dasarnya nakal", "Pembangkang", dan julukan negatif lainnya. Orang tua juga perlu mengetahui dan memahami bagaimana berkomunikasi dengan anak secara asertif dalam rangka membangun karakter mereka. Komunikasi asertif yaitu keterampilan mengekspresikan perasaaan secara jujur, terbuka, tegas, dan menghargai orang lain (Turistiati \& Nurcandrani, 2021)

2) Manusia telah mempunyai banyak sekali sumber daya di dalam dirinya untuk efektif. Kita perlu mengakses sumber daya tersebut dan menggunakannya secara bermanfaat. Orang tua mempunyai sumber daya di dalam dirinya berupa pengetahuan, pengalaman, dan atau keterampilan. Dalam hal ini dengan sumber daya yang ada orang tua dapat membangun karakter anak. Orang tua harus percaya bahwa anaknya juga mempunyai sumber daya. Dengan pengalaman dan pengetahuan orang tua dapat memberikan apresiasi pada anak sekecil apapun pencapaiannya. Capaian tersebut dapat berupa hard skills seperti kemampuan teknis, maupun soft skills berupa sikap dan perilaku yang baik.

\section{3) Peta bukanlah daerah sebenarnya.}

Orang tua perlu memahami bahwa persepsi orang tua dan anak bisa jadi berbeda. Apa yang ada dalam pikiran orang tua berdasarkan pengetahuan dan pengalamannya belum tentu sama dengan apa yang ada dalam pikiran anak.

Orang tua perlu memahami dan berusaha mencari tahu persepsi anak terlebih dahulu ketika orang tua misalnya menerapkan suatu aturan atau harapan. Misalnya, orang tua berharap anaknya tidak selalu memegang HP jika tidak sedang belajar secara daring. Orang tua sebelumnya perlu menyampaikan harapannya tidak dengan persepsi 'seharusnya anak sudah tahu'. Hal tersebut dilakukan agar harapan orang tua dipahami anak.
4) Ada sebuah niat positif yang memotivasi setiap perilaku; dan setiap perilaku punya manfaat di konteks tertentu.

Orang tua perlu berprasangka baik, berpikir dan bersikap positif jika anak melakukan sesuatu yang kurang diharapkan. Misalnya, anak-anak bermain dengan temannya dan pulang terlambat. Orang tua perlu menahan diri untuk bertanya terlebih dahulu mengapa anaknya pulang terlambat. Dengan kata lain, orang tua tidak langsung memarahi atau menuduh anak kebanyakan bermain, menyepelekan belajar atau tuduhan negatif lainnya. Anak-anak yang melakukan suatu kegiatan dan berperilaku tertentu pasti mempunyai tujuan dan motivasi.

Presuposisi ini mengajarkan bahwa dibalik semua perilaku pasti ada niat baik dan manfaat dalam konteks tertentu. Anak yang sering bermain atau dianggap banyak menghabiskan waktu dengan gadget-nya perlu diajak berbicara apa yang dia tonton atau baca di gadget-nya, dan menanyakan manfaatnya. Orang tua yang anak-anaknya TK dan SD perlu juga memberikan alternatif kegiatan yang dapat dilakukan oleh anak-anaknya selain bermain gadget. Dalam hal ini orang tua perlu memberikan contoh yang baik (role model) agar apa yang disampaikannya efektif. Artinya, jika orang tua meminta anak-anaknya tidak banyak menggunakan gadget, maka orang tuanya pun harus melakukan hal yang sama.

5) Semua hasil dan perilaku adalah pencapaian, tidak peduli apakah itu hasil yang diinginkan dalam konteks tertentu atau tidak. Setiap situasi dimana kita tidak mencapai yang kita inginkan, itu adalah feedback untuk melakukan penyesuaian.

Presuposisi ini mengingatkan orang tua bahwa sekecil apapun hasil dan perilaku yang ditunjukkan anak adalah pencapaian. Pencapaian yang kurang diharapkan, misalnya dalam konteks pendidikan, nilai anak rendah tidak sesuai yang diharapkan, maka nilai itu menjadi umpan balik bagi anak dan orang tua. Orang tua dan anakanak perlu mendiskusikan apakah nilai rendah yang diperoleh anak tersebut dikarenakan anak kurang paham, kurang belajar, atau karena faktor lain. Dari diskusi tersebut dapat dibuat suatu rencana perbaikan. 
Dalam konteks soft skills, anak-anak di usia TK dan SD perlu diberikan apresiasi dalam pencapaian mereka. Anak-anak tidak perlu dibandingkan dengan teman-temannya atau adik dan kakahnya. Pencapaian masingmasing anak berbeda-beda. Orang tua dapat membandingkan pencapaian anak dari apa yang anak lakukan sebelumnya. Misalnya, anak TK yang baru belajar menyapu tidak boleh dibandingkan kemampuan menyapunya dengan anak SD. Kemampuan anak tersebut dapat dinilai pencapaiannya dari perkembangan yang bisa dia tunjukkan dari hari ke hari sebagai dasar perbaikan jika diperlukan.

6) Penolakan adalah tanda kurangnya rapport. Apabila kita menerima respon yang tidak sesuai keinginan dari orang lain, itu adalah indikasi kita belum efektif dalam membangun rapport dengan orang itu.

Fasilitator menjelaskan perlunya orang tua membangun rapport atau hubungan baik dengan anak. Orang tua dapat berperan sebagai teman anak-anaknya sehingga anak dapat bercerita tentang masalah yang dihadapinya. Hal tersebut tergantung dari usia anak. Namun demikian, semua anak berapapun usianya akan senang jika orang tua menjadi pendengar yang baik akan ceritanya dan tahu kapan orang tua perlu memberikan saran, nasihat, atau masukan. Fasilitator melakukan role play dalam menjelaskan presuposisi ini agar para peserta lebih memahami maksudnya.

7) Pikiran dan tubuh adalah satu kesatuan. Apa yang kita pikirikan memengaruhi tubuh secara langsung, dan apa yang kita lakukan memengaruhi pikiran kita. Fasilitator menjelaskan perlunya orang tua untuk berpikir positif dan berprasangka baik pada anak-anaknya. Pikiran positif akan tercermin dari perilaku. Anak-anak tidak dapat menerima jika misalnya orang tua memukul anak atau marah-marah dengan alasan karena mereka sayang pada anaknya atau untuk menegakkan disiplin. Jika orang tua sayang pada anaknya, orang tua tidak perlu memukul tapi memberi perhatian dan menyampaikan pesannya dengan cara yang baik.
8) Bukan fokus pada segala sesuatu menjadi paling benar atau akurat, tapi paling bermanfaat.

Orang tua kadang-kadang fokus pada harapannya yang dianggap paling benar atau paling sesuai menurut persepsinya. Fasilitator memberikan ilustrasi, misalnya orang tua berharap anak laki-lakinya mempunyai potongan rambut pendek seperti prajurit. Menurut orang tua model rambut tersebut terlihat rapi dan efesien karena tak perlu disisir. Anaknya memilih model rambut yang agak gondrong dengan alasan dia merasa nyaman, dapat diterima baik oleh teman-temannya, dan menurutnya dia lebih bagus dengan potongan rambut pilihannya. Apa yang benar atau paling tepat menurut peta atau persepsi orang tua, belum tentu sama dengan persepsi anaknya. Jika orang tua memaksakan kehendaknya pada hal-hal dianggap kurang manfaat dirasa oleh anak, maka orang tua berpotensi menuai masalah. Orang tua perlu memilahmilah apa yang menjadi prioritas utama dalam membangun karakter anak.

Penjelasan setiap presuposisi diikuti oleh tanya jawab interaktif, role play, diskusi. Peserta banyak mengemukakan pengalamanpengalamannya bagaimana mereka membangun karakter anak. Pertanyaan dari peserta dicoba dijawab oleh peserta lainnya agar terjadi diskusi yang menarik. Fasilitator kemudian menyimpulkan dan memberi ulasan dari setiap tanya-jawab yang berlangsung.

Pelatihan berlangsung sekitar 3 jam kemudian dilanjutkan dengan evaluasi. Peserta diberikan lembar evaluasi sederhana mengenai pelaksanaan pelatihan. Berdasarkan evaluasi dari para peserta, secara umum semua peserta merasakan manfaat dari pelatihan yang diadakan. Para peserta berencana mengimplementasikan pengetahuan dan pemahaman yang diperoleh dari pelatihan dalam membangun karakter anaknya. Para peserta berharap bahwa di kemudian hari pelatihan serupa dapat diadakan dengan penambahan waktu agar interkasi dan diskusi dapat dilakukan lebih tuntas. Para peserta pun berharap bahwa tema-tema parenting lainnya dapat diberikan mengingat kebutuhan terhadap pengetahuan dan keterampilan tersebut sangat bermanfaat dan diperlukan dalam kehidpan sehari-hari. 

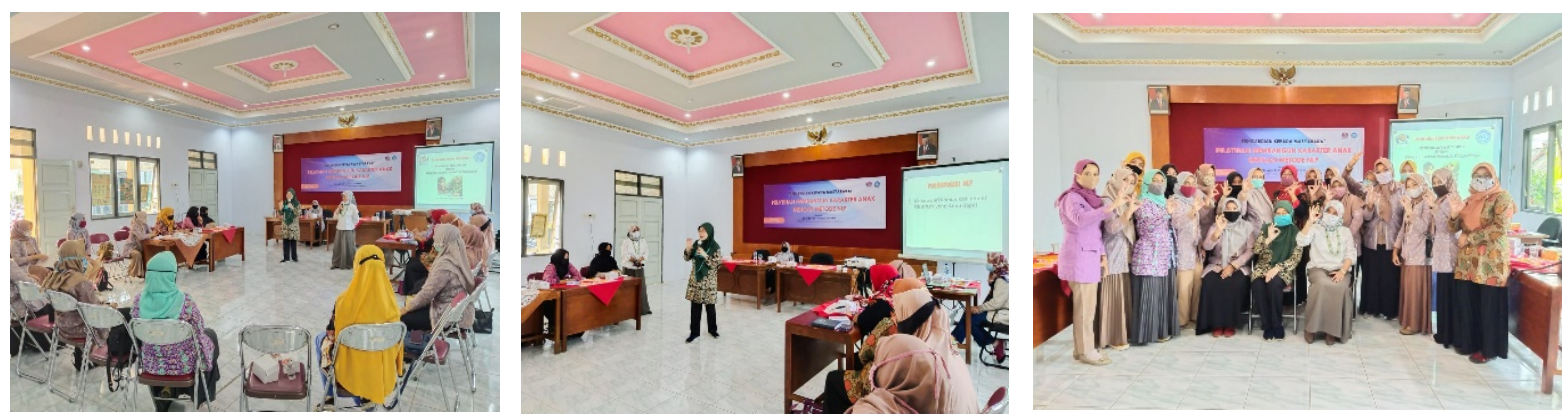

Gambar 1. Foto Kegiatan Pelatihan Membangun Karakter Anak dengan NLP di Desa Kemutug Lor

\section{KESIMPULAN \& SARAN}

Kegiatan PKM berupa pelatihan membangun karakter anak dengan NLP (Neuro Linguistic Programming) untuk Anggota TPPKK Desa Kumutug Lor, Banyumas berlangsung dengan lancar dan interaktif. Para peserta belajar mengenai 8 presuposisi NLP sebagai bekal bagi mereka untuk dapat berkomunikasi secara efektif dalam rangka membangun karakter anak.

Agar pelaksanaan PKM berlangsung lebih efektif, di kemudian hari waktu pelaksanaanya ditambah, misalnya minimal 6 jam. Beberapa anak usia SD dan SMP yang orang tuanya ikut pelatihan dapat diikutsertakan ketika ada acara diskusi. Hal ini penting untuk mengetahui harapan anak terhadap orang tuanya dalam berkomunikasi untuk membangun karakter anak.

\section{UCAPAN TERIMA KASIH}

Penulis mengucapkan terima kasih kepada Universitas Amikom Purwokerto yang telah mendukung terselenggaranya pelatihan ini. Penulis juga mengucapkan terima kasih kepada Kepala Desa Kemutug Lor, pengurus dan anggota TP-PKK Kemutug Lor atas partisipasi dan dukungannya sehingga acara pelatihan ini terlaksana dengan baik dan dapat memberikan manfaat praktis.

\section{DAFTAR PUSTAKA}

Hingdranata, N. (2014). Licensed Practitioner of Neuro Linguistic Programming. Inspirasi Indonesia.

Keezhatta, M. S. (2019). The Impact of NeuroLinguistic Programming on English Language Teaching: Perceptions of NLPTrained English Teachers. International Journal of English Linguistics, 9(6), 454465.

https://doi.org/10.5539/ijel.v9n6p454

Nurul Yani, W. O. (2018). Komunikasi
Intrapribadi Dalam Membentuk Sikap Percaya Diri Melalui Neuro Linguistic Programming. Dialektika. Dialektika, Jurnal Ilmu Komunikasi, 5(2).

Turistiati, A. T. (2019). Pelatihan Komunikasi Efektif dalam Pembentukan Karakter Anak di Cilendek Barat dan Timur Kecamatan Bogor Barat. Jurnal PKM Abdi Moestopo, 2(1). https://doi.org/https://doi.org/10.32509/a m.v2i1.691

Turistiati, A. T., \& Nurcandrani, P. S. (2021). Pelatihan Komunikasi Asertif Bagi Kader ASI Hebat Jejaring Kesehatan Purwokerto Utara. JURDIMAS, (Jurnal Pengabdian Kepada Masyarakat) Royal, 4(1). https://doi.org/https://doi.org/10.33330/ju rdimas.v4i1.944

Wikipedia. (2021). Kemutug Lor, Baturraden, Banyumas.

https://id.wikipedia.org/wiki/Kemutug_L or,_Baturraden,_Banyumas 